\title{
Comparison of the Methods for Determining Pyrogenically Modified Carbon Compounds
}

\author{
A. A. Dymov ${ }^{a}$ * , V. V. Startsev ${ }^{a}$, N. M. Gorbach ${ }^{a}$, I. N. Pausova ${ }^{a}$, D. N. Gabov ${ }^{a}$, and O. Donnerhack ${ }^{b}$ \\ ${ }^{a}$ Institute of Biology, Komi Scientific Center, Ural Branch, Russian Academy of Sciences, \\ ul. Kommunisticheskaya 28, Syktyvkar, 167982 Russia \\ ${ }^{b}$ Institute of Soil Science, Leibniz Universität Hannover, Herrenhäuser Str. 2, Hannover, 30419 Germany \\ *e-mail:aadymov@gmail.com \\ Received February 26, 2021; revised April 25, 2021; accepted April 27, 2021
}

\begin{abstract}
The soil organic matter (SOM) is searched for the biomarkers and specific features associated with the effect of wildfires by the case study of peat soil, Rheic Hemic Histosol (Lignic), in the south of the middle taiga of the Komi Republic. It is shown that fires considerably influence the peat organic matter. Pyrogenic activity is assessed according to the content of charcoal particles. SOM is examined using solid-state ${ }^{13} \mathrm{C}$-NMR spectroscopy to determine the concentrations of polycyclic aromatic hydrocarbons (PAHs) and benzene polycarboxylic acids (BPCAs). The used methods allow for diagnosing the effects of wildfires on the SOM composition. In the horizons with the signs of pyrogenesis, the share of carbon represented by aromatic fragments increases as well as the PAH concentration, mainly at the expense of naphthalene, phenanthrene, and chrysene. The carbon stock of pyrogenically modified compounds, amounting to $4.4 \mathrm{~kg} / \mathrm{m}^{2}$, is for the first time assessed in the European north based on the BPCA content. The characteristics of pyrogenically changed organic compounds and their fragments obtained by different methods correlate well: the Pearson coefficient for the correlation of the carbon content in aromatic compounds (Caryl) with total BPCA content is $R=0.84(p<0.05)$ and with individual BPCAs, $R=0.81-0.90(p<0.05)$.
\end{abstract}

Keywords: PyC, peat, wildfires, Histosols, NMR, PAHs, BPCAs

DOI: $10.1134 / \mathrm{S} 1064229321110065$

\section{INTRODUCTION}

Wildfires are among the major factors that change the terrestrial ecosystems of the globe [28, 32, 34, 57]. The ecosystems of northern latitudes contain considerable reserve of materials potentially subjected to fire $[11,23,53]$. Forest litter, peat, ground vegetation, and tree canopy are the first to be affected by wildfire. The pyrogenic activity in boreal forests during the Holocene was different. Depending on the mean annual air temperature and amount of precipitation, the intensity and frequency of wildfires differed between individual stages of the Holocene [4, 12, 14, 30, 35].

Currently, the carbon of pyrogenically modified organic compounds $(\mathrm{PyC})$ is regarded as one of the most stable pools of soil carbon resistant to microbiological decomposition [10, 54, 55]. As is believed, PyC can persist in soil to several thousand years [49]. That is why, PyC in many recent studies is regarded as an important pool of the carbon sequestered from the atmosphere [38, 39]. Many researchers believe that $\mathrm{PyC}$ is promising for the leveling of the effect of increasing carbon dioxide concentration in the atmosphere. Although the PyC importance in ecosystems is generally accepted, any unified approaches to its noti- fication in soil are still absent [45]. The earlier studies has shown that the content of polycyclic aromatic hydrocarbons (PAHs) increase manifold during wildfires [24, 26, 47]. Part of researchers relates the PyC content with the aromatic fractions in the region of 110-165 ppm on NMR spectra [50].

The interest in the bog ecosystems and different aspects in their function is ever increasing [9]. As has been shown, peats contain considerable amounts of carbon, including PyC [50]. Peat fires have catastrophic consequences $[7,8,58]$. Peatlands occupy about $10 \%$ of the territory of the Komi Republic [22]. The geobotanical composition [5], morphology, and some chemical properties of the peat soils in the plain part of the Komi Republic have been so far studied in sufficient detail and the composition of peat organic matter in the northern regions has been comprehensively described $[21,51,56]$. However, the effects of wildfires on the chemical properties of peat soils in the European north are absent.

The goal of the work was to assess the applicability of different modern methods to assaying the carbon content in pyrogenically modified organic compounds by the case study of peat soil. 

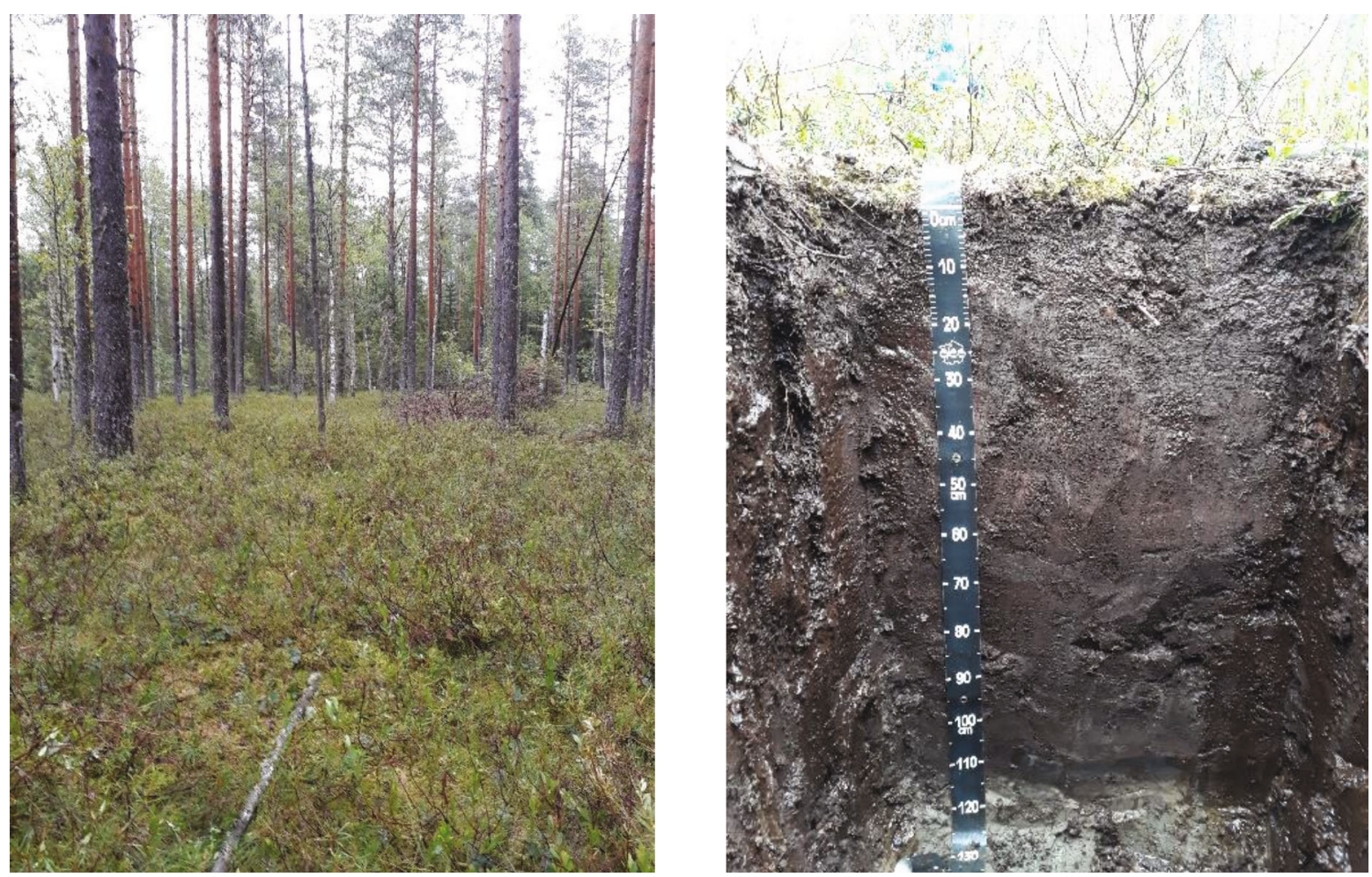

Fig. 1. Landscape and horizonation of soil profile.

\section{OBJECTS AND METHODS}

The field studies were conducted in August of 2019. A peatland under a Ledum-sphagnum pine stand near the Koigorodsky National Park was selected as the object of the study. The national park occupies the offshoots of the Northern Uvaly, dividing the basins of the Volga and the Northern Dvina Rivers [2]. According to the soil - geographic zoning [19], this territory is at the boundary between the middle taiga LuzaSysol'sky region of podzol and bog-podzol soils and the southern taiga Letka region of soddy-podzolic soils. The mean annual air temperature there is $1-2^{\circ} \mathrm{C}$, and precipitation, $800 \mathrm{~mm}(400-500 \mathrm{~mm}$ in the summer season) [1]. Figure 1 shows the landscape and general appearance of soil profiles of the area. The soil profile comprises a peat layer with underlying mineral $G$ horizon. According to the Russian classification, the soil belongs to a peat oligotrophic type [20] and according to the WRB, to Rheic Hemic Histosol (Lignic). The soil profile comprises TO1 $(0-10 \mathrm{~cm})-\mathrm{T} 2 \operatorname{pyr}(10-15 \mathrm{~cm})-$ T3 $(15-30 \mathrm{~cm})-\mathrm{T} 4(30-50 \mathrm{~cm})-\mathrm{T} 5(50-70 \mathrm{~cm})-\mathrm{T} 6$ $(70-90 \mathrm{~cm})-\mathrm{T} 7 \mathrm{pyr}(90-105 \mathrm{~cm})-\mathrm{T} 8 \mathrm{pyr}(105-115 \mathrm{~cm})-$ $\mathrm{G}(115-130 \mathrm{~cm})$ horizons. The organic part of the profile consists of plant residues at different stages of decomposition: from fresh moss mat (degree of decomposition, 5-10\%) to moderately and well decomposed lower moss horizons (25-30\% of decomposition to a depth of $70 \mathrm{~cm}$ ). The peat color varies from yellowbrown through brown to dark brown, respectively.
Carbon-bearing inclusions, suggesting a wildfire, are observed in the T2pyr horizon at a depth of $10-15 \mathrm{~cm}$. Starting from the depth of $70 \mathrm{~cm}$, the peat layer is represented by organomineral depositions with a high humus content. Presumably, peat accumulation started there with waterlogging after a wildfire. The bulk density of the horizon was determined in triplicate using an auger of $50 \mathrm{~cm}^{3}$.

The quantitative chemical analyses of soils were performed in the certified ecoanalytic laboratory and in the Department of Soil Science, Institute of Biology, Komi Scientific Center, Russian Academy of Sciences (certificate no. RU.0001.511257 of September 2019). The total organic carbon and nitrogen contents were determined in an EA-1100 (Carlo Erba) elemental analyzer; $\mathrm{pH}$, in an Edge HI2002-02 (Hanna Instruments, Romania) $\mathrm{pH}$-meter with a digital electrode $( \pm 0.01 \mathrm{pH})$ at a soil to solution ratio of $1: 25$ for litter and $1: 2.5$ for mineral horizons. The exchangeable cations were extracted using a mechanical programmed extractor with subsequent detection of cations in solution $\left(\mathrm{Ca}^{2+}, \mathrm{Mg}^{2+}, \mathrm{Na}^{+}\right.$, and $\left.\mathrm{K}^{+}\right)$by inductively coupled plasma atomic emission spectroscopy [60]. The age of the sediments was determined by radiocarbon dating of peat samples at the Institute of Monitoring of Climatic and Ecological Systems, Siberian Branch, Russian Academy of Sciences by liquid scintillation method in a Quantulus spectrometer-radiometer (Joint Access Tomographic Center, Siberian Branch, Russian Acad- 
emy of Sciences). The carbon dating was calibrated to a real age using Calib Rev 7.10 [25]. The contents of stable ${ }^{13} \mathrm{C}$ and ${ }^{15} \mathrm{~N}$ isotopes were determined at the Institute of Soil Science, Leibniz Universität (Hannover, Germany).

The charcoal particles in peat were counted according to the classical protocol [12, 52]. Peat $\left(1 \mathrm{~cm}^{3}\right)$ was sampled each $2 \mathrm{~cm}$; the sample was supplemented with $5 \% \mathrm{NaOCl}$ water solution and kept at a room temperature for $24 \mathrm{~h}$, washed with distilled water on a sieve (mesh $125 \mu \mathrm{m}$ ), and placed into a Petri dish. Then, the charcoal macroparticles were counted using a stereomicroscope (multiplication, $\times 40$ ). The counts of particles were recorded in an Excel table to further analyze using Clam and Char Analysis in the R programming environment [46].

In the Clam program, the depths of the taken samples were interpolated to age to compute the model of the rate of increase in the vertical peat layer to obtain the median values. The obtained information was then compared to the concentration of charcoal macroparticles and input to Char Analysis to get the data on charcoal accumulation rate and reliable wildfire events. To distinguish the fires of a local level, the program computes the data and suggests the background and threshold levels of the black carbon accumulation rate. The background values are the low-frequency oscillations of charcoal accumulation rate, which to a greater degree reflect a regional signal of wildfire dynamics as well as a number of parameters, such as possible inaccuracies in sample preparation and analysis, the factor of decomposition of burnt residues within the peat column, and redeposition of earlier sedimented charcoal particles. The threshold value implies that the "noises" (Signal-to-Noise Index) follow a Gaussian distribution of admixtures within a specified time window. A window of 1000 years was used to unify the statistical functions; 95th percentile was set as the threshold for noise distribution. If the determined values of charcoal particles accumulation rate were higher than the threshold, this was regarded as a reliable local fire event.

Determination of PAH content. The system of an accelerated extraction with the ASE-350 (Dionex Corporation, United States) solvents was used for a complete extraction of PAHs from soil. A peat sample $(1 \mathrm{~g})$ was placed into an extraction cell and extracted three times with a mixture of methylene chloride and acetone $(1: 1)$ at a temperature of $100^{\circ} \mathrm{C}$. The extracts were concentrated in a Kuderna-Danish apparatus in a thermostat at $70^{\circ} \mathrm{C}$, and the solvent was replaced with hexane. The resulting concentrate of the sample (volume, $3 \mathrm{~cm}^{3}$ ) was purified from organic impurities by column chromatography using aluminum oxide (Brockmann activity II) and $30 \mathrm{~cm}^{3}$ of hexane and methylene chloride mixture $(4: 1)$ as an eluent. The eluate was concentrated in a Kuderna-Danish apparatus in a thermostat at a temperature of $85^{\circ} \mathrm{C}$ to a volume of $5 \mathrm{~cm}^{3}$, supplemented with $3 \mathrm{~cm}^{3}$ of acetonitrile, and boiled down at a temperature of $90^{\circ} \mathrm{C}$ to the complete the removal of hexane. The contents of 15 individual PAHs were determined. The degree of PAH carcinogenicity was assessed by reducing all studied polyarenes to the carcinogenicity of benzo $(a)$ pyrene (BaP equivalent), which was calculated according to the index of toxicity and the content of polyarenes in soils [15].

Water-soluble organic matter (WOM). The contents of carbon $\left(\mathrm{C}_{\text {WOM }}\right)$ and nitrogen $\left(\mathrm{N}_{\mathrm{WOM}}\right)$ of watersoluble organic compounds were determined in a TOC-VCPN (Shimadzu, Japan) with a TNM-1 unit. The water-soluble substances were extracted with deionized water (ELGA LabWater, United Kingdom) at a room temperature $\left(20-23^{\circ} \mathrm{C}\right)$, at soil to water ratio of $1: 50$ for the mineral horizons and $1: 100$ for the organic horizons in BIOFIL tubes and filtered through quartz filters (MN, Germany; mesh, $0.4 \mu \mathrm{m}$ ) immediately after shaking in a Millipore device.

Chromatographic fractionation of labile (alkali-soluble matter) was performed according to Milanovsky [13] on a $1 \times 10 \mathrm{~cm}$ column filled with hydrophobized agarose gel (Octyl Sepharose CL-4B, Pharmacia) using a BioLogic LP (Bio-Rad, United States) chromatography system. The alkaline extracts $(0.1 \mathrm{M} \mathrm{NaOH})$ at a soil to solution ratio of $1: 10$ were assayed (see [13] for the detailed protocol). The carbon content in alkaline extracts was determined by wet combustion with a chromic mixture. The extinction coefficients were calculated at two wavelengths, 465 and $650 \mathrm{~nm}$, in a KFK3 photocolorimeter [16].

NMR spectroscopy. The composition of organic matter was determined by solid-state ${ }^{13} \mathrm{C}$-NMR spectroscopy; the ${ }^{13} \mathrm{C}-\mathrm{NMR}$ spectra were recorded in a Bruker Avance III 400 WB (Bruker, Germany) spectrometer with an operating frequency of $100.53 \mathrm{MHz}$ using CP-MAS (cross polarization magic angle spinning) at the Research Park of St. Petersburg State University, resource center "Magnetic Resonance Methods" (sample spinning frequency, $12.5 \mathrm{kHz}$; contact time, $2 \mathrm{~ms}$; and relaxation time, $2 \mathrm{~s}$ ). The chemical shifts are shown relative to tetramethylsilane with a shift of $0 \mathrm{ppm}$; the peak of adamantane was used as a standard. The samples were preliminaryly treated with $10 \%$ hydrofluoric acid to remove the paramagnetic admixtures of iron isotopes $[43,59]$. Numerical integration over the regions corresponding to the positions of functional groups and molecular fragments was used for semi-quantitative processing (TopSpin 3.2 software package; Bruker, Germany).

The content of aromatic structures (AR) was determined according to the summed areas of the signals at $110-145$ and $145-165 \mathrm{ppm}$ and of aliphatic structures (AL), according to the summed areas of the signals at $0-110$, and $165-185 \mathrm{ppm}$. The degree of organic matter decomposition was assessed according to the ratio of alkyl $(0-45 \mathrm{ppm})$ to $\mathrm{O}, \mathrm{N}$-alkyl (45-110 ppm) [27]. 
Determination of BPCA content. The concentrations of BPCAs in soil samples were determined according to the data by Brodowski et al. [31] at the Institute of Soil Science, Leibniz Universität (Hannover, Germany). To remove the polyvalent metals, a soil sample $(\sim 1 \mathrm{~g})$ was treated with $10 \mathrm{~mL}$ of $4 \mathrm{M}$ trifluoroacetic acid at $105^{\circ} \mathrm{C}$ for $4 \mathrm{~h}$. After cooling, the residue was several times washed with deionized water via filtration through a Whatman GF/F glass fiber filter and dried at $40^{\circ} \mathrm{C}$ for $3 \mathrm{~h}$. The residue was then transferred to reactors, supplemented with $4 \mathrm{~mL}$ of $65 \% \mathrm{HNO}_{3}$, and combusted at $170^{\circ} \mathrm{C}$ for $8 \mathrm{~h}$ in a highpressure reactor. The mixture was quantitatively transferred and filtered through a Whatman 1450-055 cellulose filter into $25-\mathrm{cm}^{3}$ calibrated flasks. Then, a $4-\mathrm{cm}^{3}$ aliquot was diluted with deionized water and supplemented with $100 \mu \mathrm{L}$ of citric acid as the first internal standard. The solution was passed through cation exchange resin (Dowex $50 \mathrm{WX8}$; mesh, 200-400); the water samples were freeze-dried and dissolved in methanol. 2,2'-Biphenyl dicarboxylic acid $(100 \mu \mathrm{L})$ in methanol was added as the second internal standard. After drying in the atmosphere of nitrogen, the samples were derivatized for $2 \mathrm{~h}$ at $90^{\circ} \mathrm{C}$ using N,O-bis(trimethylsilyl)trifluoroacetamide (BSTFA) and N-trimethylsilyl iodide (TMSI) at a ratio of 49: 1 [29]. The BPCAs were identified in an HP 6890 (Agilent Technologies, United States) gas chromatograph with a flame ionization detector. Six BPCAs were used as standards [42]. In total, the contents of eight BPCAs were determined. It is recommended to use the acids carrying more than four carboxyl groups when calculating the PyC content since the acids with a smaller number of carboxyl groups may be of a biotic origin [41, 44]. Ba4 was calculated as the sum of pyromellitic, mellophanic, and prehnitic acids. The $\mathrm{Ba} 4 / \mathrm{Ba} 6$ and $\mathrm{Ba} 5 / \mathrm{Ba} 6$ ratios were used ( $\mathrm{Ba} 5$ is the carbon content in benzene pentacarboxylic acid and $\mathrm{Ba} 6$, in mellitic acid).

\section{RESULTS AND DISCUSSION}

The age of the studied peatland is about 9000 years. Note that this peatland repeatedly experienced wildfires both during the Holocene and in modern times. The content of charcoal particles suggests that the most active wildfires in this peatland took place in the Atlantic and Subboreal periods (Fig. 2). Presumably, large peaks suggest that the upper organic horizon was under fire. A well-pronounced pyrogenic horizon at a depth of 10-15 cm suggests a strong wildfire event approximately 140 years ago. The time since the last fire was assessed according to the age of the forest stand. The flattened parts of the plot most likely reflect the combustion of the forests adjacent to the examined plot.

Table 1 lists the physicochemical soil properties. The peat oligotrophic soil is strongly acidic $\left(\mathrm{pH}_{\mathrm{KCl}} 3.0-3.9\right)$. The upper oligotrophic peat horizon has the maximum acidity, while the acidity of the lower peat hori- zons is somewhat lower. The distribution of acidity along the soil profile is uniformly eluvial. The ash content in the soil peat horizons is $2.6-9.5 \%$. An increase (to $4.5 \%$ ) in the ash residues is observed in the pyrogenic T2pyr horizon.

The content of exchangeable bases is nonuniformly distributed along the soil profile. The content of calcium cations is maximal and is somewhat lower for the magnesium, potassium, and sodium cations. The $\mathrm{Ca}^{2+}$ content in peat horizons varied from 2.1$4.5 \mathrm{cmol}$ (equiv) $/ \mathrm{kg}$ and in the mineral horizon it was $1.5 \mathrm{cmol}$ (equiv) $/ \mathrm{kg}$. The highest content was observed in the TO1 upper horizon.

The distribution of carbon and nitrogen along the soil profile was uniform with a drastic decrease in the mineral horizons. The carbon content in the studied soil varies from $568 \mathrm{~g} / \mathrm{kg}$ in the organic and organomineral horizons to $11.5 \mathrm{~g} / \mathrm{kg}$ in mineral horizon $\mathrm{G}$. The nitrogen concentration in peat horizons is $5.5-15.0 \mathrm{~g} / \mathrm{kg}$ in the peat horizons and $0.71 \mathrm{~g} / \mathrm{kg}$ in the mineral horizon. The carbon to nitrogen ratio varies from 22 to 70 in organic horizons and to 19 in the mineral horizon. In general, the distribution of $\mathrm{C} / \mathrm{N}$ ratio along the soil profiles expectedly decreases.

Analysis of the carbon $\left(\mathrm{C}_{\mathrm{WOM}}\right)$ and nitrogen $\left(\mathrm{N}_{\mathrm{WOM}}\right)$ contents in the water-soluble organic compounds demonstrates that their maximums are observed in the upper organic horizons, represented by fresh moss mats. The WOM uniformly decreases along the soil profile. The $\mathrm{C}_{\mathrm{WOM}}$ content downward the profile changes from $3.51 \mathrm{~g} / \mathrm{kg}$ in the upper organic horizon to $0.21 \mathrm{~g} / \mathrm{kg}$ in the mineral horizon.

Chromatography of the hydrophobic interaction makes it possible to separate the mixture of alkali-soluble substances into five fractions differing in the amphiphilic properties. The hydrophilic fractions are represented by the fragments of aliphatic structure. The first fraction correlates in a statistically significant manner with the aliphatic compounds of the O-alkyl group $(R=0.76, p<0.05)$ and di-O, $\mathrm{N}$-aliphatic fragments with doubly substituted heteroatoms $(R=0.82$, $p<0.05)$. Presumably, the cellulose and hemicellulose extraction products are prevalent in this fraction. The sum of hydrophilic fractions (first and second fractions) amounted to $17-54 \%$. The content of the first hydrophilic fraction in the soil profile varied from 8.6 to $45.6 \%$ and of the second fraction, from 5.9 to $11.8 \%$. The maximum content was observed in the TO1 horizon, represented by a fresh moss mat. The distribution of alkalisoluble hydrophilic compounds in general follows the WOM distribution in the soil profile. The correlation coefficient between the first fraction and $\mathrm{C}_{\mathrm{WOM}}$ is $R=$ $0.72(p<0.05)$ and with $\mathrm{N}_{\text {WOM }}, R=0.73(p<0.05)$. The share of hydrophilic compounds decreases with depth. Chromatography fractionation demonstrates a high content of the fractions of the alkali-soluble organic matter associated with lignin- and cellulose-like compounds [13], belonging to the hydrophobic fractions 


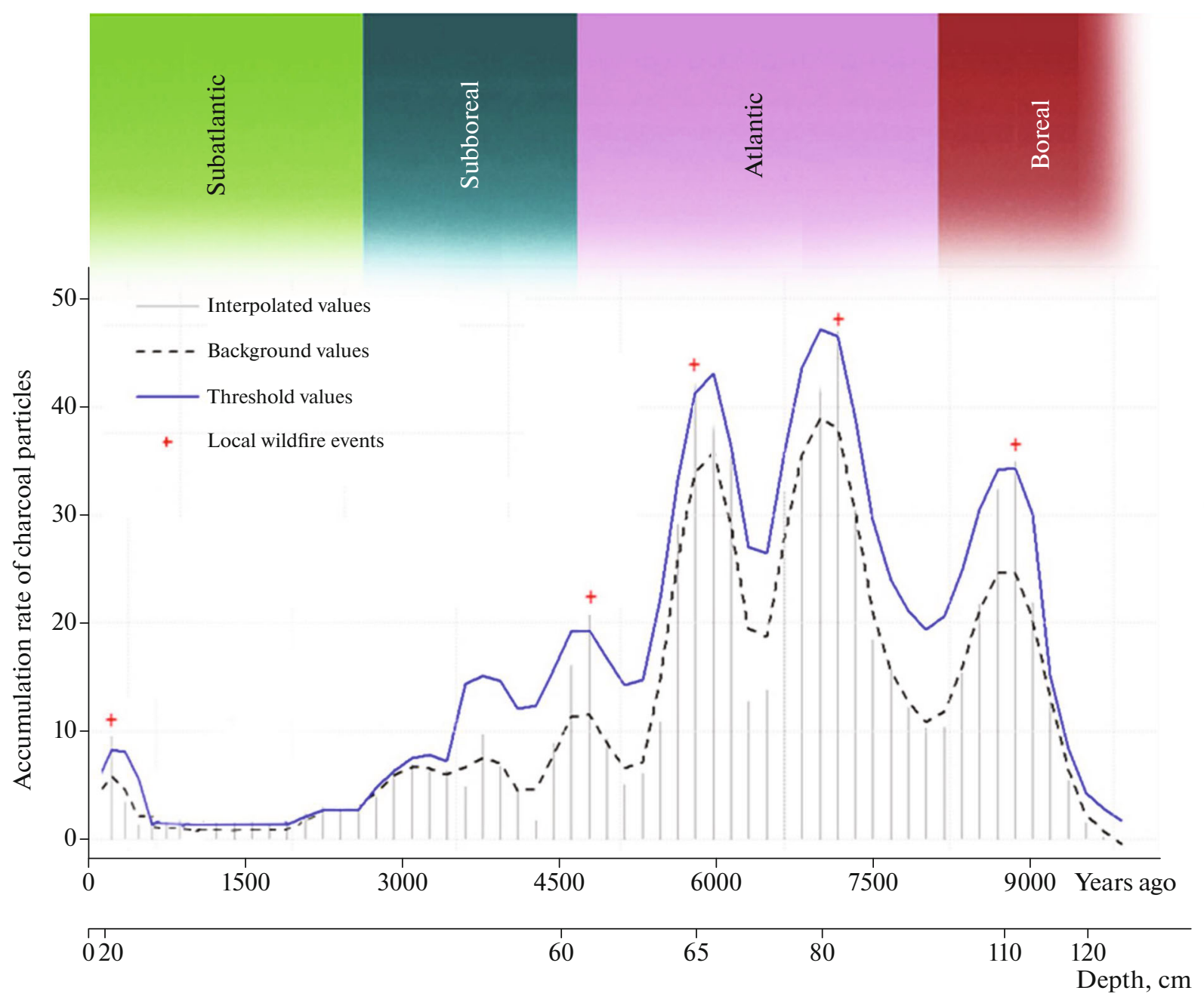

Fig. 2. Charcoal particles content (number of particles $/ \mathrm{cm}^{2} \mathrm{yr}$ ) in studied soil.

(third and fourth fractions) in the studied soil profile (Table 2). The third fraction varied in the profile from 16.1 to $51.3 \%$; the fourth, from 28.0 to $40.3 \%$; and the content of the fifth fraction was insignificant (0.9$3.0 \%)$. Note that the role of carbon content in the water-soluble compounds and individual amphiphilic fractions is less important as an indicator when studying the effects of the wildfires of the past as compared with the current wildfires in the forest ecosystems on mineral soils [6].

Hydrophilic organic compounds mainly belong to the mobile SOM components, which readily dissolve and migrate in soil profile. Under stagnant moistening in bog ecosystems, hydrophilic fractions accumulate only in the upper horizon of peat soils. The middle and low peat horizons are rich in hydrophobic fractions (46-83\%), represented by the biopolymers from plant residues with different degrees of decomposition. Presumably, an increase in the content of hydrophobic fractions, represented by high-molecular weight structural components, including those of aromatic nature, can indirectly reflect a pyrogenic influence. The $E_{465} / E_{650}$ ratio is minimal in the T2pyr horizon and maximal in the horizon of fresh moss mat at a depth of $0-10 \mathrm{~cm}$. As for the remaining peat horizons, the values vary from 4.6 to 6.3. However, any significant effect of pyrogenesis on the composition of alkali-soluble organic matter and the content of amphiphilic fractions is unobservable.

Note that the studied soil contains rather large amount of total carbon $\left(184 \mathrm{~kg} \mathrm{C} / \mathrm{m}^{2}\right)$ and nitrogen $\left(4.6 \mathrm{~kg} \mathrm{~N} / \mathrm{m}^{2}\right)$. These values are significantly higher as compared with the estimates for the soils of the region based on the data for the unforested bogs with the calculated density values and not the field data [17]. Most likely, the high values are associated with the periodical wildfires, which result not only in the input of partially charred particles with a high carbon content, but also in an increase in the bulk density of peat. An increase in density in the pyrogenic horizons has been earlier described for the soils of Central Siberia [7]. 


\begin{tabular}{|c|c|c|c|c|c|c|c|c|c|}
\hline 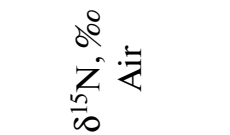 & $\vec{i}$ & $\stackrel{\infty}{\leftrightarrow}$ & $\stackrel{t}{0}$ & $\stackrel{5}{a}$ & $\stackrel{m}{\rightarrow}$ & $\stackrel{\text { f }}{\stackrel{-}{2}}$ & $\stackrel{0}{0}$ & $\begin{array}{l}\text { So } \\
\stackrel{i}{i}\end{array}$ & \\
\hline 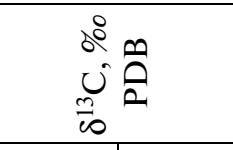 & $\begin{array}{l}0 \\
0 \\
0 \\
0 \\
1\end{array}$ & $\begin{array}{l}\infty \\
\infty \\
\infty \\
\stackrel{\leftrightarrow}{0} \\
\uparrow\end{array}$ & $\begin{array}{l}\stackrel{0}{0} \\
\dot{0} \\
i\end{array}$ & 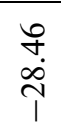 & $\begin{array}{l}\overline{\mathbf{i}} \\
\text { iे }\end{array}$ & $\begin{array}{l}\overrightarrow{\text { mे }} \\
\text { iे }\end{array}$ & 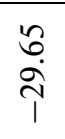 & $\begin{array}{l}\text { ते } \\
\text { iे }\end{array}$ & 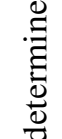 \\
\hline$\sum_{0,0}^{\tilde{E}}$ & $\begin{array}{l}m \\
0 \\
0 \\
+1 \\
0 \\
0 \\
0 \\
0\end{array}$ & 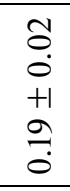 & $\begin{array}{l}\tilde{\tilde{O}} \\
0 \\
+1 \\
\stackrel{0}{0} \\
0\end{array}$ & $\begin{array}{l}\overline{0} \\
0 \\
+1 \\
\tilde{N} \\
0\end{array}$ & $\begin{array}{l}\overrightarrow{0} \\
0 \\
+1 \\
\tilde{n} \\
0 \\
0\end{array}$ & $\begin{array}{l} \\
\\
0 \\
0 \\
+1 \\
0 \\
0 \\
0 \\
0\end{array}$ & 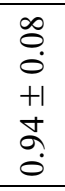 & 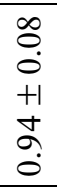 & $\stackrel{\circ}{\circ}$ \\
\hline \multirow{2}{*}{ 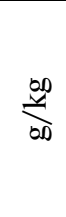 } & ָิ & $\stackrel{\infty}{0}$ & $\stackrel{\circ}{0}$ & $\stackrel{\infty}{\circ}$ & $\stackrel{\circ}{0}$ & $\stackrel{\circ}{0}$ & $\hat{o}$ & $\stackrel{+}{\circ}$ & $\overrightarrow{0}$ \\
\hline & $\bar{n}$ & $\stackrel{\widetilde{m}}{=}$ & $\stackrel{m}{m}$ & $\stackrel{\circ}{\stackrel{O}{-}}$ & $\stackrel{q}{\rightarrow}$ & 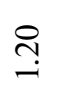 & $\stackrel{0}{\infty}$ & $\stackrel{R}{0}$ & $\bar{\jmath}$ \\
\hline \multirow{2}{*}{ de } & $\underset{i}{0}$ & $\stackrel{n}{+}$ & $\stackrel{\circ}{i}$ & $\hat{i}$ & $\stackrel{\infty}{i}$ & $\underset{\sim}{\dot{m}}$ & $\tilde{a}$ & $\underset{n}{\stackrel{d}{n}}$ & $\stackrel{+}{\stackrel{\alpha}{\alpha}}$ \\
\hline & $\simeq$ & in & $r$ & $n$ & $\nabla$ & $\sigma$ & in & $a$ & तิ \\
\hline \multirow{6}{*}{ 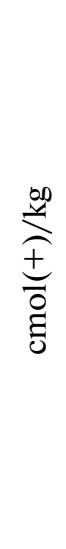 } & \& & $\Xi$ & F & $\infty$ & $\stackrel{\varrho}{\varrho}$ & aे & $\hat{a}$ & r & $\cong$ \\
\hline & $\stackrel{+}{0}$ & $\hat{n}$ & $\stackrel{\circ}{\dot{m}}$ & $\hat{i}$ & $\dot{m}$ & $\stackrel{\circ}{+}$ & $\stackrel{n}{\sim}$ & $\stackrel{\sim}{\sim}$ & $\stackrel{b}{i}$ \\
\hline & $\stackrel{\infty}{0}$ & $\stackrel{\partial}{0}$ & $\hat{a}$ & $\hat{0}$ & $\hat{o}$ & $\stackrel{\text { oे }}{0}$ & $\stackrel{\infty}{\circ}$ & $\hat{o}$ & $\begin{array}{l}\dot{0} \\
\dot{0}\end{array}$ \\
\hline & $\hat{\hat{i}}$ & $\stackrel{q}{+}$ & $\stackrel{\infty}{\circ}$ & $\stackrel{n}{0}$ & $\stackrel{t}{0}$ & $\begin{array}{l}\text { t. } \\
\stackrel{0}{0}\end{array}$ & $\stackrel{0}{\circ}$ & त्रे & $\stackrel{\infty}{0}$ \\
\hline & $\stackrel{\infty}{i}$ & $\stackrel{m}{-}$ & $\hat{o}$ & $\stackrel{0}{0}$ & $\dot{o}$ & $\stackrel{\circ}{-}$ & $\exists$ & $\stackrel{\infty}{0}$ & $\stackrel{\circ}{-}$ \\
\hline & $\stackrel{n}{+}$ & $\bar{F}$ & Iี & $\stackrel{\circ}{i}$ & $\vec{i}$ & $\vec{i}$ & $\stackrel{\sim}{n}$ & $\vec{i}$ & $\because$ \\
\hline zu & $F$ & 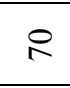 & f & $\bar{n}$ & is & in & $\bar{n}$ & ה & $\stackrel{2}{ }$ \\
\hline$\stackrel{200}{=}$ & $\begin{array}{l}n \\
\stackrel{n}{+1} \\
\dot{+1} \\
\dot{m}\end{array}$ & $\begin{array}{l}0 \\
\dot{+} \\
+1 \\
n \\
n \\
a\end{array}$ & $\begin{array}{l}0 \\
\dot{+} \\
+1 \\
0 \\
\dot{g} \\
\underline{a}\end{array}$ & $\begin{array}{c}\stackrel{\Upsilon}{+} \\
+1 \\
\stackrel{+1}{=}\end{array}$ & $\begin{array}{l}\stackrel{0}{+} \\
+1 \\
\stackrel{+1}{ \pm}\end{array}$ & $\begin{array}{l}\stackrel{+}{+} \\
+1 \\
+ \\
\stackrel{0}{\oplus}\end{array}$ & 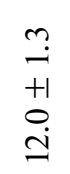 & $\begin{array}{l}\exists \\
= \\
+1 \\
n \\
n \\
\text { in }\end{array}$ & $\begin{array}{l} \pm \\
0 \\
+1 \\
+1 \\
-0 \\
0\end{array}$ \\
\hline on & $\begin{array}{l}= \\
+1 \\
+1 \\
\infty \\
\delta\end{array}$ & 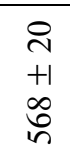 & $\begin{array}{l}\stackrel{9}{2} \\
+1 \\
\text { f } \\
\text { I }\end{array}$ & $\begin{array}{l}= \\
\overline{+} \\
+1 \\
\bar{\sigma}\end{array}$ & $\begin{array}{l}9 \\
+1 \\
F \\
\text { f }\end{array}$ & $\begin{array}{l}9 \\
+1 \\
n \\
i n\end{array}$ & $\begin{array}{l}\text { aे } \\
+1 \\
\text { ते }\end{array}$ & 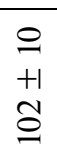 & $\begin{array}{l}\hat{i} \\
+1 \\
n \\
=\end{array}$ \\
\hline O) & $\stackrel{+}{+}$ & $\bar{F}$ & $\stackrel{n}{+}$ & $\stackrel{n}{+}$ & $\stackrel{n}{+}$ & $\stackrel{\infty}{+}$ & $\stackrel{b}{+}$ & $\dot{+}$ & $\stackrel{\vartheta}{\dot{\gamma}}$ \\
\hline$\vec{v}$ & $\stackrel{\dot{m}}{\dot{m}}$ & $\vec{m}$ & $\stackrel{\sim}{\sim}$ & $\stackrel{\infty}{m}$ & $\stackrel{m}{m}$ & $\ddot{m}$ & $\hat{m}$ & $\vec{m}$ & $\stackrel{\infty}{\dot{m}}$ \\
\hline 䇏 & $\frac{0}{1}$ & $\begin{array}{l}n \\
\underline{1}\end{array}$ & $\begin{array}{l}0 \\
1 \\
n\end{array}$ & $\begin{array}{l}\text { in } \\
\text { i } \\
\stackrel{n}{n}\end{array}$ & $\begin{array}{l}\text { i } \\
i \\
\text { in }\end{array}$ & $\begin{array}{l}\stackrel{2}{1} \\
i \\
i\end{array}$ & $\begin{array}{l}\stackrel{n}{a} \\
\frac{1}{a} \\
a\end{array}$ & $\begin{array}{l}\cong \\
= \\
1 \\
\varrho\end{array}$ & $\begin{array}{l}0 \\
n \\
1 \\
\cong\end{array}$ \\
\hline $\begin{array}{l}\tilde{0} \\
\stackrel{0}{0} \\
\text { I }\end{array}$ & $\underset{\vdash}{\circ}$ & 空 & $\rho$ & $\stackrel{\ddagger}{\ddagger}$ & $\stackrel{n}{n}$ & 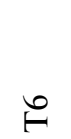 & 总 & $\stackrel{\overrightarrow{0}}{\hat{0}}$ & 0 \\
\hline
\end{tabular}


Table 2. Relative content of amphiphilic fractions in SOM (\%), content of alkali-soluble organic matter, and ratio of extinction coefficients

\begin{tabular}{|c|c|c|c|c|c|c|c|c|c|c|}
\hline \multirow{2}{*}{ Horizon } & \multirow{2}{*}{ Depth, cm } & \multirow{2}{*}{$\begin{array}{c}\omega(\mathrm{C}) 0.1 \mathrm{M} \\
\mathrm{NaOH}, \%\end{array}$} & \multirow{2}{*}{$\begin{array}{l}\mathrm{C}_{\text {alk }}, \% \\
\text { of } \mathrm{C}_{\text {tot }}\end{array}$} & \multirow{2}{*}{$E_{465} / E_{650}$} & \multicolumn{5}{|c|}{ Number of chromatography fraction } & \multirow{2}{*}{$\mathrm{Dh}^{*}$} \\
\hline & & & & & 1 & 2 & 3 & 4 & 5 & \\
\hline $\mathrm{TO} 1$ & $0-10$ & $5.51 \pm 0.04$ & 11.4 & 8.1 & 45.6 & 8.6 & 16.1 & 28.0 & 1.7 & 1.18 \\
\hline T2pyr & $10-15$ & $8.69 \pm 0.05$ & 17.9 & 4.3 & 17.6 & 8.1 & 34.0 & 38.7 & 1.5 & 0.35 \\
\hline $\mathrm{T} 3$ & $15-30$ & $14.2 \pm 0.3$ & 29.3 & 5.5 & 12.2 & 11.8 & 51.3 & 23.7 & 1.1 & 0.32 \\
\hline $\mathrm{T} 4$ & $30-50$ & $13.85 \pm 0.07$ & 28.6 & 5.5 & 12.6 & 9.2 & 44.4 & 32.5 & 1.3 & 0.28 \\
\hline $\mathrm{T} 5$ & $50-70$ & $16.7 \pm 0.05$ & 34.4 & 5.2 & 9.8 & 6.5 & 44.4 & 36.3 & 3.0 & 0.20 \\
\hline T6 & $70-90$ & $18.43 \pm 0.23$ & 35.8 & 4.9 & 8.6 & 8.3 & 45.9 & 36.0 & 1.3 & 0.20 \\
\hline T7pyr & $90-105$ & $4.01 \pm 0.06$ & 38.0 & 6.3 & 12.1 & 5.9 & 40.8 & 40.3 & 0.90 & 0.22 \\
\hline T8pyr & $105-115$ & $0.235 \pm 0.001$ & 8.3 & 5.9 & 29.7 & 8.0 & 33.6 & 28.7 & Not detected & 0.61 \\
\hline
\end{tabular}

* $\mathrm{Dh}-$ degree of hydrophily, the ratio of the sum of hydrophilic (first and second) fractions to the sum of hydrophobic (third-fifth) fractions.

Table 3. Relative content (\%) of molecular fragments in SOM according to CP-MAS ${ }^{13} \mathrm{C}-\mathrm{NMR}$ spectroscopy

\begin{tabular}{|c|c|c|c|c|c|c|c|c|c|c|c|c|}
\hline \multirow{3}{*}{ Horizon } & \multirow{3}{*}{ Depth, cm } & \multirow{2}{*}{\begin{tabular}{|l} 
Alkyl C \\
$\mathrm{C}_{\text {Alk-H }}$
\end{tabular}} & \multicolumn{3}{|c|}{ O-Alkyl C } & \multicolumn{2}{|c|}{ Aryl C } & \multicolumn{2}{|c|}{$\begin{array}{l}\text { Carboxyl C/ } \\
\text { amide/ester }\end{array}$} & \multirow{3}{*}{$\begin{array}{c}\text { Alkyl/ } \\
\text { O,N-alkyl }\end{array}$} & \multirow{3}{*}{$\mathrm{AR} / \mathrm{AL}$} & \multirow{3}{*}{$\begin{array}{c}\text { Caryl, } \\
\% *\end{array}$} \\
\hline & & & $\mathrm{C}_{\mathrm{CH}_{3}-\mathrm{O}}$ & $\mathrm{C}_{\mathrm{Alk}-\mathrm{O}}$ & $\mathrm{C}_{\mathrm{O}-\mathrm{Alk}-\mathrm{O}}$ & $\mathrm{C}_{\mathrm{Ar}-\mathrm{H}(\mathrm{H})}$ & $\mathrm{C}_{\mathrm{Ar}-\mathrm{O}, \mathrm{N}}$ & $\mathrm{C}_{\mathrm{COOH}(\mathrm{R})}$ & $\mathrm{C}_{\mathrm{C}=0}$ & & & \\
\hline & & $0-45$ & $45-60$ & $60-95$ & $95-110$ & $110-145$ & $145-165$ & $165-185$ & $185-220$ & & & \\
\hline TO1 & $0-10$ & 16.0 & 7.0 & 45.4 & 11.6 & 11.3 & 4.6 & 3.9 & 0.1 & 0.2 & 0.2 & 7.7 \\
\hline T2pyr & $10-15$ & 19.1 & 5.9 & 18.0 & 6.8 & 36.4 & 8.0 & 5.0 & 0.9 & 0.6 & 0.9 & 25.2 \\
\hline $\mathrm{T} 3$ & $15-30$ & 39.2 & 7.4 & 21.4 & 6.3 & 14.5 & 5.3 & 4.7 & 1.1 & 1.1 & 0.3 & 10.7 \\
\hline $\mathrm{T} 4$ & $30-50$ & 38.3 & 7.2 & 20.4 & 6.3 & 15.9 & 5.7 & 4.7 & 1.4 & 1.1 & 0.3 & 10.6 \\
\hline T5 & $50-70$ & 36.3 & 7.2 & 18.7 & 6.4 & 17.9 & 6.8 & 5.2 & 1.5 & 1.1 & 0.4 & 13.4 \\
\hline T6 & $70-90$ & 42.5 & 7.1 & 14.7 & 5.6 & 18.5 & 6.6 & 4.6 & 0.4 & 1.5 & 0.4 & 13.9 \\
\hline T7pyr & $90-105$ & 44.2 & 6.4 & 12.0 & 4.2 & 18.7 & 6.8 & 5.6 & 2.2 & 2.0 & 0.4 & 13.5 \\
\hline T8pyr & $105-115$ & 34.0 & 6.9 & 13.9 & 6.0 & 24.4 & 7.9 & 7.0 & - & 1.3 & 0.5 & 3.3 \\
\hline
\end{tabular}

* Calculated taking into account the carbon content in individual horizon; hereinafter, dash denotes the amount below the determination limit.

The increase in soil density here is associated with the input of ash $(R=0.98, p<0.05)$.

Figure 3 shows NMR spectra of the organic matter in the horizons of studied profile and Table 3 lists the integration results. The contents of fragments in SOM primarily depend on the composition of plants having accumulated in the peatland. In particular, characteristic of the upper peat horizons, mainly represented by mosses and weakly decomposed residues, is the prevalence of polysaccharides on the background of a small share of aromatic components. The composition of organic matter at depths of $15-105 \mathrm{~cm}$ remains sufficiently stable, with the aliphatic fragments accounting for $39-44 \%$. The cellulose-like substances account for 12 to $21 \%$; the share of methoxyl fragments is rather low, amounting to approximately $6-7 \%$; and the share of hemicellulose $\left(\mathrm{C}_{\mathrm{O} \text {-Alk-O }}\right)$ does not exceed $7 \%$. The content of aromatic components (the characteristic frequently related to the effect of pyrogenesis) considerably increases in the T2pyr $(10-15 \mathrm{~cm})$ and T8pyr $(105-115 \mathrm{~cm})$ horizons, which carry rather large amount of black carbon. The share of aryl fragments, represented by the compounds at 110-145 and 145$165 \mathrm{ppm}$, elevates in these horizons to $32.3-44.4 \%$.

Analysis of the stable isotopes in organic matter shows a certain increase in the ${ }^{13} \mathrm{C}$ and ${ }^{15} \mathrm{~N}$, thus displaying a heavier isotopic composition, in the pyrogenic horizon at the depth of $10-15 \mathrm{~cm}$ as compared with the higher and lower peat horizons. Statistically significant correlations with the content of $\mathrm{C}_{4-6}$ BPCAs $(R=0.87$, $p<0.05)$ are observed.

The PAH content is frequently used in diagnostics and assessment of the effects of wildfires on SOM composition $[6,61,62]$. The PAH concentrations in the studied soil horizons are considerably different 


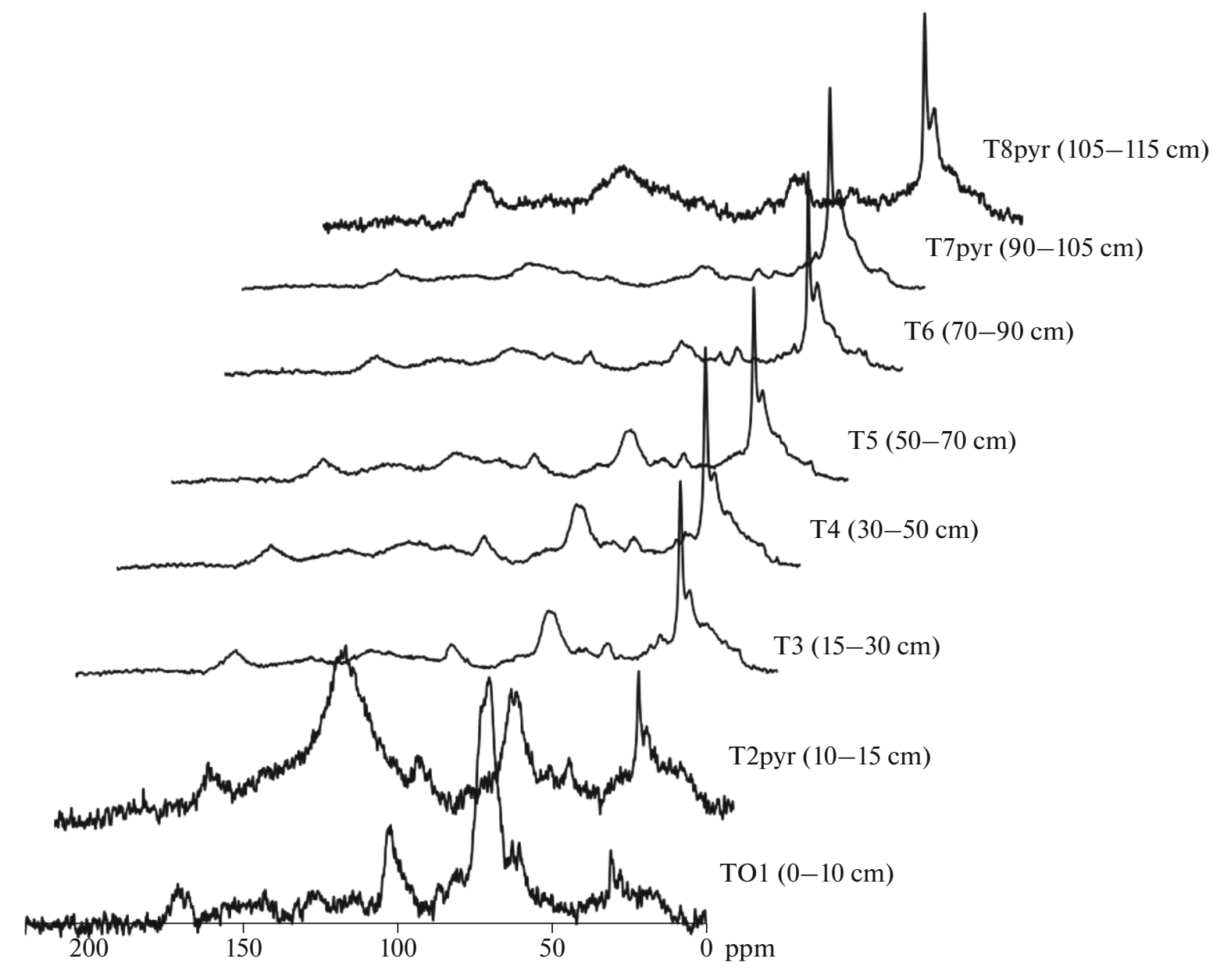

Fig. 3. NMR spectra of the studied soil horizons.

(Table 4). The horizons with pronounced pyrogenic signs display a considerable increase in both the total $\mathrm{PAH}$ content and the contents of individual compounds. Presumably, a pyrogenic origin is characteristic of naphthalene, phenanthrene, fluoranthene, and chrysene. As has been shown, these compounds are the main contributors to an increase in the PAH content in the postpyrogenic automorphic boreal soils [6, 36]. A considerable increase in the share of heavy 5-ring PAHs is observable in the lower horizons $(90-105 \mathrm{~cm})$. The concentrations of benzo $(k)$ fluoranthene and dibenzo $(a, h)$ anthracene are rather high, which is explainable with a biogenic factor [40]. The total PAH stock in the considered soil is $4.7 \mathrm{~g} / \mathrm{m}^{2}$.

The carcinogenic hazard of PAHs in the studied soils is most pronounced in the T2pyr, T7pyr, and T8pyr horizons (Table 4). The anthropogenic emission was assessed using the quantitative ratio of "technogenic" to "natural" PAHs, namely, (PYR + BaPYR)/(PHEN + CRY), where PYR, BaPYR, PHEN, and CRY are the modules of pyrene, benzo $(a)$ pyrene, phenanthrene, and chrysene inputs, respectively. The value of this ratio exceeding unity suggests the presence of polyarenes from "pyrogenic" sources. According to our data, the pyrogenic component is the most pronounced in the T7pyr horizon (6.9), indicating that the polyarenes formed by combustion of organic substances are prevalent.

For the PAHs with a relative molecular weight of 178 , the ratio of anthracene to the sum of anthracene and phenanthrene, ANT/(ANT + PHEN) or ANT/178, below 0.10 demonstrates an "oil" or natural origin of these compounds versus ANT/178 $>0.10$, which indicates that the corresponding PAHs result from pyrogenesis [63]. This ratio is $<0.10$ in all examined horizons, suggesting a prevalently natural origin of the PAHs. Computation of the indicator PAH ratios that demonstrate the degree to which the observed association is "pyrogenic" or natural is not completely adequate for soils because the numerical values for the natural/technogenic boundary may significantly differ from the published data for other geographic regions.

One of the most widely used methods for assaying $\mathrm{PyC}$ is based on BPCAs; in particular, the current global PyC estimates were obtained with this method [48]. The content of BPCAs (Table 5) allows for quantifica- 


\begin{tabular}{|c|c|c|c|c|c|c|c|c|c|c|c|}
\hline \multicolumn{2}{|r|}{$\Xi$} & 으 & $\nabla$ & $=$ & શे & 0 & 0 & $\stackrel{\text { g }}{n}$ & \& & 0 & 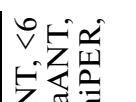 \\
\hline \multicolumn{2}{|r|}{$=$} & $\begin{array}{l}0 \\
0 \\
0\end{array}$ & $\stackrel{\text { Oे }}{0}$ & $\begin{array}{l}\text { Oे } \\
\text { o. }\end{array}$ & $\begin{array}{l}0 \\
0 \\
0\end{array}$ & $\begin{array}{l}n \\
0 \\
0\end{array}$ & $\begin{array}{l}0 \\
0 \\
0\end{array}$ & $\stackrel{0}{0}$ & $\begin{array}{l}n \\
0 \\
0\end{array}$ & $\begin{array}{l}\hat{n} \\
0 \\
0\end{array}$ & \\
\hline \multicolumn{2}{|r|}{-} & $\ddot{\sigma}$ & $\stackrel{n}{0}$ & $\begin{array}{l}0 \\
0 \\
0\end{array}$ & $\begin{array}{l}8 \\
0\end{array}$ & 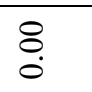 & $\begin{array}{l}8 \\
0\end{array}$ & $\begin{array}{l}\infty \\
\infty \\
0 \\
0\end{array}$ & $\stackrel{0}{0}$ & $\begin{array}{l}8 \\
0\end{array}$ & $\therefore$ \\
\hline \multicolumn{2}{|r|}{ 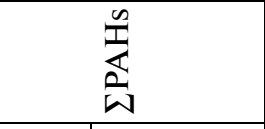 } & $\stackrel{n}{n}$ & $\stackrel{\Xi}{\varrho}$ & $\tilde{\imath}$ & \& & 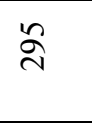 & $\widehat{\approx}$ & $\begin{array}{l}\mathcal{Y} \\
\text { J } \\
\text { I }\end{array}$ & $\begin{array}{l}0 \\
\stackrel{n}{n} \\
\infty\end{array}$ & $\stackrel{\infty}{=}$ & \\
\hline \multirow{2}{*}{. } & yXdI & $\begin{array}{l}\tilde{1} \\
+1 \\
0\end{array}$ & 1 & I & I & I & I & I & I & 1 & \\
\hline & Чヨd!Чฮิવ & $\begin{array}{l}+ \\
+1 \\
\infty\end{array}$ & I & I & I & I & $\begin{array}{l}+ \\
+1 \\
0\end{array}$ & 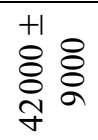 & $\begin{array}{l}+1 \\
\stackrel{\leftrightarrow}{\circ} \\
\infty \\
\infty\end{array}$ & 1 & \\
\hline \multirow{4}{*}{ 先 } & INVYEGC & $\begin{array}{l}m \\
+1 \\
n\end{array}$ & $\begin{array}{l}8 \\
+1 \\
+1 \\
8\end{array}$ & $\begin{array}{l}n \\
+1 \\
=\end{array}$ & $\begin{array}{l}m \\
+1 \\
\infty \\
\sim\end{array}$ & I & I & $\begin{array}{l}8 \\
+1 \\
+ \\
\stackrel{2}{2}\end{array}$ & $\begin{array}{l}n \\
+1 \\
n\end{array}$ & 1 & \\
\hline & yXdeg & $\stackrel{+1}{m} \tilde{0}$ & $\begin{array}{l}+ \\
+1 \\
\infty\end{array}$ & $\stackrel{+1}{+\vec{i}}$ & I & I & I & $\stackrel{+1}{\stackrel{\infty}{\infty}} \stackrel{0}{\sim}$ & 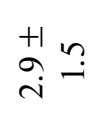 & I & \\
\hline & 겁 & $\stackrel{+1}{\infty} \stackrel{0}{0}$ & $\begin{array}{l}n \\
+1 \\
n\end{array}$ & $\stackrel{+1}{\stackrel{+}{i}} \underset{-}{\sim}$ & I & I & I & $\begin{array}{l}a \\
+1 \\
a\end{array}$ & I & 1 & \\
\hline & ㄱ૧Я & I & 1 & 1 & I & I & I & $\stackrel{+1}{6} \stackrel{\infty}{\sim}$ & I & 1 & \\
\hline \multirow{4}{*}{ 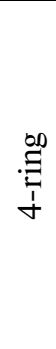 } & ХУว & 1 & $\stackrel{+1}{+} \underset{f}{+}$ & $\theta_{0}^{+1} m$ & $\stackrel{+1}{+1}$ in & I & I & $\begin{array}{l}+1 \\
i n \\
i n\end{array}$ & $\begin{array}{l}+1 \\
\stackrel{+}{+}\end{array}$ & 1 & \\
\hline & LNVEg & । & I & । & I & I & I & I & I & I & \\
\hline & yXd & I & 1 & I & I & I & I & I & I & I & \\
\hline & $\forall\urcorner A$ & I & $\underset{\sim}{+1} \simeq$ & I & I & I & I & I & I & 1 & \\
\hline \multirow{2}{*}{ 咅 } & LNV & $\stackrel{+1}{a} \stackrel{?}{i}$ & $\begin{array}{l}+1 \\
\stackrel{n}{i} \\
\dot{n}\end{array}$ & $\stackrel{+1}{\stackrel{+}{9}} \stackrel{0}{-}$ & $\stackrel{+}{+1}$ & $\stackrel{+1}{\stackrel{+}{r}} \underset{i}{i}$ & $\stackrel{+1}{\underset{+}{*}} \underset{i}{\sim}$ & $\stackrel{+}{\underset{N}{N}}=$ & $\stackrel{+1}{\oplus} \tilde{0}$ & $\begin{array}{l}+1 \\
\stackrel{n}{r}\end{array}$ & \\
\hline & N日Hd & $\stackrel{+1}{\infty} f$ & $\stackrel{\sim}{2}^{+1} 8$ & ${ }_{\infty}^{+1} 9$ & $\stackrel{+1}{\Xi}$ & $\stackrel{+1}{a} \bar{\sim}$ & $\stackrel{+1}{?}$ \& & $\stackrel{+1}{?}$ ? & $\vec{d}^{+1} \cong$ & $\stackrel{+1}{\infty} q$ & \\
\hline \multirow{3}{*}{$\stackrel{0}{\leftrightarrows}$} & ค७ษ & 1 & $\begin{array}{l}\infty \\
+1 \\
0\end{array}$ & $\begin{array}{l}+ \\
+1 \\
0\end{array}$ & $\begin{array}{l}\tilde{1} \\
+1 \\
\infty\end{array}$ & $\begin{array}{l}0 \\
+1 \\
0\end{array}$ & $\begin{array}{l}+ \\
+1 \\
=\end{array}$ & I & I & $\begin{array}{l}+ \\
+1 \\
=\end{array}$ & \\
\hline & BगV & I & 1 & 1 & 1 & 1 & 1 & I & I & 1 & \\
\hline & HdVN & $\stackrel{+1}{\circ}$ \& & 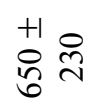 & $\stackrel{+1}{0}$ & $\stackrel{+1}{\stackrel{+}{े}}$ & $\stackrel{+1}{8} \infty$ & $\stackrel{+1}{\varrho} 8$ & $\stackrel{+1}{8}$ in & $\stackrel{+}{+} \tilde{}$ & $\underset{\sim}{+1} \pm$ & \\
\hline \multicolumn{2}{|c|}{ हैं } & $\frac{0}{1}$ & $\frac{n}{1}$ & $\begin{array}{l}0 \\
1 \\
n\end{array}$ & $\begin{array}{l}\text { in } \\
1 \\
0 \\
0\end{array}$ & $\begin{array}{l}\stackrel{0}{1} \\
\text { in }\end{array}$ & $\begin{array}{l}\stackrel{9}{1} \\
\stackrel{1}{1}\end{array}$ & $\begin{array}{l}n \\
\stackrel{0}{1} \\
0 \\
a\end{array}$ & $\begin{array}{l}n \\
\cdots \\
\stackrel{n}{0}\end{array}$ & 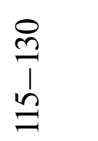 & \\
\hline \multicolumn{2}{|c|}{ 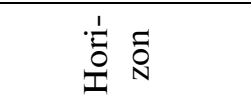 } & 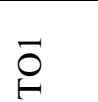 & 空 & 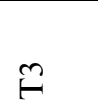 & $\stackrel{\Xi}{\ominus}$ & $n$ & 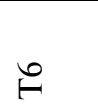 & 总 & 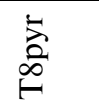 & 0 & \\
\hline
\end{tabular}


Table 5. Contents of benzene polycarboxylic acids (BPCAs) in studied soil

\begin{tabular}{|c|c|c|c|c|c|c|c|c|c|c|c|c|c|c|c|c|c|}
\hline \multirow{3}{*}{ Horizon } & \multirow{3}{*}{$\begin{array}{l}\text { Depth, } \\
\text { cm }\end{array}$} & \multicolumn{3}{|c|}{ Ba3* } & \multicolumn{3}{|c|}{$\mathrm{Ba} 4$} & \multirow{2}{*}{$\begin{array}{c}\mathrm{Ba5} \\
\mathrm{VII}\end{array}$} & \multirow{2}{*}{$\begin{array}{c}\mathrm{Ba6} \\
\mathrm{VIII}\end{array}$} & \multirow{2}{*}{$\underset{\%}{\text { Sum, }}$} & \multirow{2}{*}{$\frac{\tilde{\sigma}}{\stackrel{1}{0}}$} & \multirow{3}{*}{ 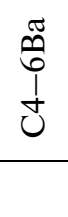 } & \multirow{3}{*}{$\frac{\tilde{\omega}}{v^{\tilde{\omega}}}$} & \multirow{3}{*}{$\frac{\tilde{n}}{v^{\tilde{n}}}$} & \multirow{3}{*}{$\sum_{0}^{j 0}$} & \multicolumn{2}{|c|}{ PyC stock } \\
\hline & & I & II & III & IV & V & VI & & & & & & & & & $u_{1}^{0}$ & $u_{1}^{0}$ \\
\hline & & \multicolumn{10}{|c|}{$\%$} & & & & & \multicolumn{2}{|c|}{$\mathrm{kg} / \mathrm{m}^{2}$} \\
\hline TO1 & $0-10$ & 0.01 & 0.06 & 0.00 & 0.06 & 0.06 & 0.07 & 0.23 & 0.21 & 0.70 & 0.32 & 0.28 & 1.00 & 1.17 & 0.65 & 0.026 & 0.022 \\
\hline T2pyr & $10-15$ & 0.45 & 0.67 & 0.00 & 0.96 & 1.82 & 1.41 & 6.58 & 6.46 & 18.36 & 8.19 & 7.61 & 0.73 & 1.07 & 14.42 & 0.78 & 0.72 \\
\hline T3 & $15-30$ & 0.01 & 0.10 & 0.00 & 0.09 & 0.10 & 0.11 & 0.67 & 0.57 & 1.65 & 0.74 & 0.68 & 0.60 & 1.22 & 1.36 & 0.21 & 0.19 \\
\hline T4 & $30-50$ & 0.02 & 0.17 & 0.01 & 0.18 & 0.20 & 0.20 & 1.40 & 1.19 & 3.37 & 1.50 & 1.40 & 0.56 & 1.24 & 3.05 & 0.63 & 0.59 \\
\hline T5 & $50-70$ & 0.02 & 0.08 & 0.01 & 0.11 & 0.16 & 0.13 & 0.53 & 0.63 & 1.67 & 0.74 & 0.69 & 0.70 & 0.89 & 1.37 & 0.34 & 0.32 \\
\hline T6 & $70-90$ & 0.01 & 0.06 & 0.00 & 0.09 & 0.14 & 0.10 & 0.46 & 0.57 & 1.44 & 0.64 & 0.60 & 0.65 & 0.85 & 1.16 & 0.33 & 0.31 \\
\hline T7pyr & $90-105$ & 0.05 & 0.15 & 0.00 & 0.27 & 0.41 & 0.38 & 0.82 & 0.71 & 2.79 & 1.27 & 1.16 & 1.67 & 1.21 & 2.39 & 1.79 & 1.64 \\
\hline T8pyr & $105-115$ & 0.08 & 0.12 & 0.00 & 0.04 & 0.04 & 0.03 & 0.71 & 0.57 & 1.58 & 0.71 & 0.61 & 0.22 & 1.32 & 6.92 & 0.67 & 0.57 \\
\hline Total & & & & & & & & & & & & & & & & 4.78 & 4.36 \\
\hline
\end{tabular}

$\mathrm{C}_{\mathrm{BPCA}}$ is carbon content in benzene polycarboxylic acids in a horizon taking into account the carbon in individual molecules. The stock is calculated taking into account the density and thickness of horizons. * Asterix denotes the number of carboxylic groups in BPCAs. Trivial (chemical) names are given: I, hemimellitic (benzene-1,2,3-tricarboxylic) acid; II, trimellitic (benzene-1,2,4-tricarboxylic) acid; III, trimesic (benzene-1,3,5-tricarboxylic) acid; IV, pyromellitic (1,2,4,5-benzene tetracarboxylic) acid; V, mellophanic (benzene1,2,3,4-tetracarboxylic) acid; VI, prehnitic (1,2,3,4-benzene tetracarboxylic) acid; VII, 1,2,3,4,5-benzene pentacarboxylic acid; and VIII, mellitic (benzene-1,2,3,4,5,6-hexacarboxylic) acid.

Table 6. Pearson correlation coefficients for some of the studied parameters

\begin{tabular}{l|c|c|c|c|c|c|c}
\hline \multicolumn{1}{c|}{ Parameter } & CAr-H(C) & AR & Caryl, \% & NAPH & PHEN & FLA & CRY \\
\hline Hemimellitic acid & $0.93^{*}$ & $0.90^{*}$ & $0.76^{*}$ & $0.93^{*}$ & $0.73^{*}$ & $0.81^{*}$ & 0.61 \\
Trimellitic acid & $0.88^{*}$ & $0.85^{*}$ & $0.80^{*}$ & $0.96^{*}$ & $0.75^{*}$ & $0.83^{*}$ & 0.65 \\
Trimesic acid & -0.22 & -0.21 & -0.03 & -0.01 & -0.07 & 0.04 & -0.29 \\
Pyromellitic acid & $0.84^{*}$ & $0.81^{*}$ & $0.88^{*}$ & $0.96^{*}$ & $0.78^{*}$ & $0.83^{*}$ & $0.73^{*}$ \\
Mellophanic acid & $0.86^{*}$ & $0.83^{*}$ & $0.88^{*}$ & $0.96^{*}$ & $0.78^{*}$ & $0.83^{*}$ & 0.70 \\
Prehnitic acid & $0.85^{*}$ & $0.81^{*}$ & $0.88^{*}$ & $0.96^{*}$ & $0.78^{*}$ & $0.82^{*}$ & $0.73^{*}$ \\
Benzene pentacarboxylic acid & $0.88^{*}$ & $0.84^{*}$ & $0.82^{*}$ & $0.98^{*}$ & $0.77^{*}$ & $0.86^{*}$ & 0.60 \\
Mellitic acid & $0.88^{*}$ & $0.85^{*}$ & $0.84^{*}$ & $0.98^{*}$ & $0.78^{*}$ & $0.87^{*}$ & 0.59 \\
Total, \% & $0.88^{*}$ & $0.84^{*}$ & $0.84^{*}$ & $0.98^{*}$ & $0.78^{*}$ & $0.86^{*}$ & 0.63 \\
C & $0.88^{*}$ & $0.84^{*}$ & $0.84^{*}$ & $0.98^{*}$ & $0.78^{*}$ & $0.86^{*}$ & 0.63 \\
\hline
\end{tabular}

* Significant at $p<0.05, n=8$.

tion of the share of pyrogenic carbon in SOM. In the studied soil, the total BPCA content varies from 0.7 to $18.4 \mathrm{wt} \%$ or 0.3 to $8.2 \%$ recalculated to carbon, which accounts for 0.6 to $14.4 \%$ of the total carbon content in soil horizons. The highest PyC content is observed in the pyrogenic horizon at the depth of $10-15 \mathrm{~cm}$, most likely resulting from a wildfire that took place 140 years ago. The effect of the wildfires involved in the formation of this peatland and occurring about 9000 years ago enhanced $\mathrm{PyC}$ accumulation in the lower horizons at the amount of $2.4-6.9 \%$ of total carbon content. Recalculation of the PyC stock taking into account the bulk densities of individual horizons gave the PyC estimate of $4.78 \mathrm{~kg} / \mathrm{m}^{2}$ (considering all eight BPCAs) or $4.36 \mathrm{~kg} / \mathrm{m}^{2}$ considering only $4-6$-ring acids. Note that only a few papers report the data on the
BPCA content on the territory of Russia and mainly refer to the automorphic soils of Siberia. The data on the $\mathrm{PyC}$ content in peats are sparse. We have obtained somewhat higher values of the PyC stock and content as compared with the peat soils in the forest-tundra of the Krasnoyarsk krai (Russia) [44]. This is explainable by that the studied area is more southern and, correspondingly, more subject to wildfires both now and in different periods of the Holocene. The observed PyC content in the studied soil is considerably higher as compared with podzols [33].

Our results suggest that most of the used approaches make it possible to diagnose the pyrogenic signs in SOM. Moreover, many characteristics correlate well with one another. The most significant correlation coefficients are listed in Table 6. The total BPCA content 
significantly correlates with the concentrations of naphthalene $(R=0.98, p<0.05)$, phenanthrene $(R=0.78$, $p<0.05)$, fluoranthene $(R=0.86, p<0.05)$, and the aromatic fragments $\left(\mathrm{C}_{\mathrm{Ar}-\mathrm{H}(\mathrm{C})}\right)$ identified with $\mathrm{NMR}$ spectroscopy $(R=0.88, p<0.05)$. Note that the total $\mathrm{PAH}$ content correlates only with the total carbon content in a sample. The significant correlations with a high coefficient are observed for individual BPCAs and several PAHs. Except for trimesic acid, the correlation coefficients of individual BPCAs with naphthalene amount to $0.96-0.98(p<0.05)$; with phenanthrene, to $0.75-0.78(p<0.05)$; with fluoranthene, to $0.82-0.86$ $(p<0.05)$; and with chrysene, to $0.73-0.74(p<0.05)$.

\section{CONCLUSIONS}

A comparison of the NMR spectroscopy data and PAH contents has shown that these methods make it possible to diagnose the input of pyrogenically modified organic compounds. The share of the carbon associated with benzene rings considerably increases in the SOM molecular fragments with pyrogenic signs. The concentrations of naphthalene, fluoranthene, phenanthrene, and chrysene, which have putative pyrogenic origin, are increased in the PAHs of the horizons. An increase in the content of molecular aromatic fragments and several individual PAHs can be used as markers of pyrogenesis. These parameters can indicate only the general trend of an increase in the degree of SOM aromaticity. The total PAH stock is extremely small and the PAH concentrations only partially characterize the total content of $\mathrm{PyC}$ and its stock in soils.

The method relying on BPCAs gives a more realistic data on the PyC stock in soils. A hard acid hydrolysis allows for extraction of a large amount of aromatic carbon from soil, which better reflects its concentration. Correspondingly, this method is more adequate for quantification of pyrogenic carbon.

\section{FUNDING}

The work was supported by the Russian Foundation for Basic Research (project no. 19-29-05111mk) and German Academic Exchange Service, DAAD (project no. 91760908).

\section{CONFLICT OF INTEREST}

The authors declare that they have no conflicts of interest.

\section{OPEN ACCESS}

This article is licensed under a Creative Commons Attribution 4.0 International License, which permits use, sharing, adaptation, distribution and reproduction in any medium or format, as long as you give appropriate credit to the original author(s) and the source, provide a link to the Creative Commons license, and indicate if changes were made. The images or other third party material in this article are included in the article's Creative Commons license, unless indicated otherwise in a credit line to the material. If material is not included in the article's Creative Commons license and your intended use is not permitted by statutory regulation or exceeds the permitted use, you will need to obtain permission directly from the copyright holder. To view a copy of this license, visit http://creativecommons.org/licenses/by/4.0/.

\section{REFERENCES}

1. Atlas on Climate and Hydrology of the Komi Republic, Ed. by A. I. Taskaev (Nauka, Moscow, 1997) [in Russian].

2. V. A. Varsanof'eva, Geomorphology. Industrial Forces of Komi ASSR, Vol. 1: Geological Structure and Mineral Resources (Izd. Akad. Nauk SSSR, Moscow, 1953), pp. $257-270$

3. I. M. Gabbasova, R. R. Suleimanov, R. N. Sitdikov, and T. T. Garipov, "Pyrogenic degradation of drained peat soils," Eurasian Soil Sci. 38, 642-647 (2005).

4. Yu. V. Golubeva, "Climate and vegetation in the Holocene of the Komi Republic," Litosfera, No. 2, 124-128 (2008).

5. S. V. Degteva and N. N. Goncharova, "Protection of mires in the Komi Republic," Izv. Komi Nauchn. Tsentra, Ural. Otd., Ross. Akad. Nauk, No. 10, 29-35 (2012).

6. A. A. Dymov, Soil Successions in Boreal Forests of the Komi Republic (GEOS, Moscow, 2020) [in Russian]. https://doi.org/10.34756/GEOS.2020.10.37828

7. T. T. Efremova and S. P. Efremov, "Pyrogenic transformation of organic matter in soils of forest bogs," Eurasian Soil Sci. 39, 1297-1305 (2006). https://doi.org/10.1134/S106422930

8. F. R. Zaidel'man, Mineral and Peat Soils in Sandy Glaciofluvial (Polessie) Landscapes: Genesis, Hydrology, Agroecology, Amelioration, Rehabilitation, and Fire Control of Peat Soils and Forests (Krasand, Moscow, 2013) [in Russian].

9. L.I. Inisheva, "Peat soils: genesis and classification," Eurasian Soil Sci. 39, 699-704 (2006). https://doi.org/10.1134/S1064229306070027

10. P. V. Krasilnikov, "Stable carbon compounds in soils: their origin and functions," Eurasian Soil Sci. 48, 9971008 (2015). https://doi.org/10.1134/s1064229315090069

11. Yu. N. Krasnoshchekov, "Soils of mountain forests and their transformation under the impact of fires in Baikal region,” Eurasian Soil Sci. 51, 371-384 (2018). https://doi.org/10.1134/S1064229318040099

12. D. A. Kupriyanov and E. Yu. Novenko, "Reconstruction of the Holocene dynamics of forest fires in the central part of Meshcherskaya Lowlands according to antracological analysis," Contemp. Probl. Ecol. 12, 204212 (2019). https://doi.org/10.1134/S1995425519030065

13. E. Yu. Milanovskii, Soil Humic Substances as Natural Hydrophobic-Hydrophilic Compounds (GEOS, Moscow, 2009) [in Russian].

14. E. Yu. Novenko, N. G. Mazei, D. A. Kupriyanov, E. M. Volkova, and A. N. Tsyganov, "Holocene dynamics of vegetation and ecological conditions in the center of the East European Plain,” Russ. J. Ecol. 49, 
218-225 (2018). https://doi.org/10.1134/S1067413618030062

15. A. Yu. Opekunov, E. S. Mitrofanova, and M. G. Opekunova, "Technogenic transformation of the composition of bottom sediments of rivers and canals of St. Petersburg," Geoekol., Inzh. Geol., Gidroekol., Geokriol., No. 4, 48-61 (2017).

16. D. S. Orlov, L. K. Sadovnikova, and N. I. Sukhanova, Chemistry of Soils (Vysshaya Shkola, Moscow, 2005) [in Russian].

17. A. V. Pastukhov and D. A. Kaverin, "Soil carbon pools in tundra and taiga ecosystems of northeastern $\mathrm{Eu}-$ rope,” Eurasian Soil Sci. 46, 958-967 (2013). https://doi.org/10.1134/S1064229313070077

18. A. V. Pastukhov and D. A. Kaverin, "Ecological state of peat plateaus in Northeastern European Russia," Russ. J. Ecol. 47, 125-132 (2016). https://doi.org/10.1134/S1067413616010100

19. Podzolic Soils of the Central and Eastern Parts of European Territory of the USSR (Nauka, Leningrad, 1981), pp. 118-152.

20. Field Guide for Identification of Russian Soils (Moscow, 2008) [in Russian].

21. M. P. Sartakov, "NMR spectroscopy of 13 humic acids from peats in Central Ob River region," Khim. Rastit. Syr'ya, No. 3, 135-139 (2008).

22. Peat Resources of the Komi Republic (Syktyvkar, 2000) [in Russian].

23. V. V. Furyaev, Role of Fires in Forestation Processes (Nauka, Novosibirsk, 1996) [in Russian].

24. A. S. Tsibart and A. N. Gennadiev, "The influence of fires on the properties of forest soils in the Amur River basin (the Norskii Reserve)," Eurasian Soil Sci. 41, 686-693 (2008). https://doi.org/10.1134/S1064229308070028

25. O. A. Chichagova, Radiocarbon Dating of Soil Humus (Nauka, Moscow, 1985) [in Russian].

26. E. Abakumov, A. Pechkin, E. Chebykina (Maksimova), and G. Shamilishvili, "Effect of the wildfires on sandy podzol soils of Nadym region, Yamalo-Nenets Autonomous District, Russia,” Appl. Environ. Soil Sci. 2020, 8846005 (2020). https://doi.org/10.1155/2020/8846005

27. J. A. Baldock and C. M. Preston, "Chemistry of carbon decomposition processes in forests as revealed by solidstate carbon-13 nuclear magnetic resonance," in Carbon Forms and Functions in Forest Soils (Madison, WI, 1995), pp. 89-117.

28. A. Bento-Gonçalves, A. Vieira, X. Úbeda, and D. Martin, "Fire and soils: key concepts and recent advances," Geoderma 191, 3-13 (2012).

https://doi.org/10.1016/j.geoderma.2012.01.004

29. J. J. Birk, M. Dippold, G. L. B. Wiesenberg, and B. Glaser, "Combined quantification of faecal sterols, stanols, stanones and bile acids in soils and terrestrial sediments by gas chromatography-mass spectrometry,” J. Chromatogr. A. 1242, 1-10 (2012).

https://doi.org/10.1016/j.chroma.2012.04.027

30. M. V. Bobrovsky, D. A. Kupriaynov, and L. G. Khanina, "Anthracological and morphological analysis of soils for the reconstruction of the forest ecosystem history (Meshchera Lowlands, Russia)," Quat. Int. 516,
70-82 (2019).

https://doi.org/10.1016/j.quaint.2018.06.033

31. S. Brodowski, A. Rodionov, L. Haumaier, B. Glaser, and W. Amelung, "Revised black carbon assessment using benzene polycarboxylic acids," Org. Geochem. 36, 1299-1310 (2005).

https://doi.org/10.1016/j.orggeochem.2005.03.011

32. G. Certini, "Fire as a soil-forming factor," Ambio 43, 191-195 (2014).

https://doi.org/10.1007/s13280-013-0418-2

33. C. I. Czimczik, M. W. I. Schmidt, and E. D. Schulze, "Effects of increasing fire frequency on black carbon and organic matter in podzols of Siberian Scots pine forests," Eur. J. Soil Sci. 56, 417-428 (2005). https://doi.org/10.1111/j.1365-2389.2004.00665.x

34. S. H. Doerr and C. Santın, "Global trends in wildfire and its impacts: perceptions versus realities in a changing world," Philos. Trans. R. Soc., B 371, 1-10 (2016). https://doi.org/10.1098/rstb.2015.0345

35. K. N. Dyakonov, E. Yu. Novenko, I. V. Mironenko, D. A. Kuprijanov, and M. V. Bobrovsky, "The role of fires in the Holocene landscape dynamics of the southeastern part of Meshchera lowlands," Dokl. Earth Sci. 477, 1336-1342 (2017). https://doi.org/10.1134/S1028334X17110125

36. A. A. Dymov, D. N. Gabov, and E. Yu. Milanovskii, ${ }^{~}{ }^{13} \mathrm{C}-\mathrm{NMR}$, PAHs, WSOC and repellence of fire affected soils (albic podzols, Russia)," Environ. Earth Sci. 76, 1-10 (2017). https://doi.org/10.1007/s12665-017-6600-2

37. A. A. Dymov and D. N. Gabov, "Pyrogenic alterations of podzols at the North-East European part of Russia: morphology, carbon pools, PAH content," Geoderma 241-242, 230-237 (2015). https://doi.org/10.1016/j.geoderma.2014.11.021

38. M. Egli, G. Mastrolonardo, R. Seiler, S. Raimondi, F. Favilli, V. Crimi, R. Krebs, P. Cherubini, and G. Certini, "Charcoal and stable soil organic matter as indicators of fire frequency, climate and past vegetation in volcanic soils of Mt. Etna, Sicily," Catena 88, 14-26 (2012). https://doi.org/10.1016/j.catena.2011.08.006

39. M. S. Forbes, R. J. Raison, and J. O. Skjemstad, "Formation, transformation and transport of black carbon (charcoal) in terrestrial and aquatic ecosystems," Sci. Total Environ. 370, 190-206 (2006).

https://doi.org/10.1016/j.scitotenv.2006.06.007

40. D. N. Gabov, Ye. V. Yakovleva, and R. S. Vasilevich, "Vertical distribution of PAHs during the evolution of permafrost peatlands of the European arctic zone," Appl. Geochem. 123, 104790 (2020).

https://doi.org/10.1016/j.apgeochem.2020.104790

41. B. Glaser, PhD Thesis (University of Bayreuth, Bayreuth, 1999).

42. B. Glaser, L. Haumaier, G. Guggenberger, and W. Zech, "Black carbon in soils: the use of benzenecarboxylic acids as specific markers," Org. Geochem. 29, 811-819 (1998).

43. C. N. Gonçalves, R. S. D. Dalmolin, D. P. Dick, H. Knicker, E. Klamt, and I. Kögel-Knabner, "The effect of $10 \%$ HF treatment on resolution of CPMAS 
${ }^{13} \mathrm{C}$ NMR spectra and on the quality of organic matter in ferralsols," Geoderma 116, 373-392 (2003).

44. G. Guggenberger, A. Rodionov, O. Shibistova, M. Grabe, O. A. Kasansky, H. Fuchs, N. Mikheyeva, G. Zrazhevskaya, and H. Flessa, "Storage and mobility of black carbon in permafrost soils of the forest tundra ecotone in Northern Siberia," Global Change Biol. 14, 1367-1381 (2008). https://doi.org/10.1111/j.1365-2486.2008.01568.x

45. K. Hammes, M. W. I. Schmidt, R. J. Smernik, et al., "Comparison of quantification methods to measure fire-derived (black/elemental) carbon in soils and sediments using reference materials from soil, water, sediment and the atmosphere," Global Biogeochem. Cycles 21, GB3016 (2007).

https://doi.org/10.1029/2006GB002914

46. P. Higuera, CharAnalysis 0.9: Diagnostic and Analytical Tools for Sediment Charcoal Analysis. User's Guide (Montana State University, Bozeman, MT, 2009).

47. IUSS Working Group WRB," World Reference Base for Soil Resources 2014, Update 2015, International Soil Classification System for Naming Soils and Creating Legends for Soil Maps, World Soil Resources Reports No. 106 (UN Food and Agriculture Organization, Rome, 2015).

48. M. W. Jones, A. I. Coppola, C. Santín, T. Dittmar, R. Jaffé, S. H. Doerr, and T. A. Quine, "Fires prime terrestrial organic carbon for riverine export to the global oceans," Nat. Commun. 11, 2791 (2020).

https://doi.org/10.1038/s41467-020-16576-z

49. Y. Kuzyakov, I. Bogomolova, and B. Glaser, "Biochar stability in soil: decomposition during eight years and transformation as assessed by compound specific ${ }^{14}$ C analysis," Soil Biol. Biochem. 70, 229-236 (2014). https://doi.org/10.1016/j.soilbio.2013.12.021

50. J. Leifeld, C. Alewell, C. Bader, J. P. Krüger, C. W. Mueller, M. Sommer, M. Steffens, and S. Szidat, "Pyrogenic carbon contributes substantially to carbon storage in intact and degraded northern peatlands," Land Degrad. Dev. 29, 2082-2091 (2018).

https://doi.org/10.1002/ldr.2812

51. E. D. Lodygin, I. I. Alekseev, R. S. Vasilevich, and E. V. Abakumov, "Complexation of lead and cadmium ions with humic acids from arctic peat soils," Environ. Res. 191, (2020). https://doi.org/10.1016/j.envres.2020.110058

52. S. Mooney and W. Tinner, "The analysis of charcoal in peat and organic sediments," Mires Peats 7, 1-18 (2011).

53. P. Pereira, A. Cerdà, A. J. Lopez, L. M. Zavala, J. MataixSolera, V. Arcenegui, I. Misiune, S. Keesstra, and A. Novara, "Short-term vegetation recovery after a grassland fire in Lithuania: The effects of fire severity, slope position and aspect," Land Degrad. Dev. 27,
1523-1534 (2016). https://doi.org/10.1002/ldr.2498

54. C. M. Preston and M. W. I. Schmidt, "Black (pyrogenic) carbon: a synthesis of current knowledge and uncertainties with special consideration of boreal regions," Biogeosciences 3 (4), 397-420 (2006).

55. M. Reisser, R. S. Purves, M. W. I. Schmidt and S. Abiven, "Pyrogenic carbon in soils: a literature-based inventory and a global estimation of its content in soil organic carbon and stocks,” Front. Earth Sci. 4, 1-14 (2016). https://doi.org/10.3389/feart.2016.00080

56. M. P. Sartakov, A. A. Novikov, and N. V. Chukhareva, "Study of humic acids in various types and kinds of peats at Khantymansi autonomous area-Ygra by ${ }^{13} \mathrm{C}$ spectroscopy," Int. J. Pharm. Technol. 8 (2), 14204-14213 (2016).

57. C. Santin, S. H. Doerr, M. W. Jones, A. Merino, C. Warneke, and J. M. Roberts, "The relevance of pyrogenic carbon for carbon budgets from fires: Insights from the FIREX experiment," Global Biogeochem. Cycles 34, e2020GB006647 (2020). https://doi.org/10.1029/2020GB006647

58. A. A. Sirin, M. A. Medvedeva, D. A. Makarov, A. A. Maslov, and H. Joosten, "Multispectral satellite based monitoring of land cover change and associated fire reduction after large-scale peatland rewetting following the 2010 peat fires in Moscow Region (Russia),” Ecol. Eng. 158, 106044 (2020). https://doi.org/10.1016/j.ecoleng.2020.106044

59. J. O. Skjemstad, P. Clarke, J. A. Taylor, J. M. Oades and R. H. Newman, "The removal of magnetic materials from surface soils-a solid state ${ }^{13} \mathrm{C} \mathrm{CP} / \mathrm{MAS}$ NMR study," Aust. J. Soil Res. 32, 1215-1229 (1994). https://doi.org/10.1071/SR9941215

60. Procedures for Soil Analysis: Technical Paper No. 9, Ed. by L. P. van Reeuwijk (International Soil Reference and Information Centre, Wageningen, 2002).

61. A. Vergnoux, L. Malleret, L. Asia, P. Doumenq, and F. Theraulaz, "Impact of forest fires on PAH level and distribution in soils," Environ. Res. 111, 193-198 (2011). https://doi.org/10.1016/j.envres.2010.01.008

62. D. B. Wiedemeier, S. Brodowski, and G. L.B. Wiesenberg, "Pyrogenic molecular markers: Linking PAH with BPCA analysis," Chemosphere 119, 432-437 (2015). https://doi.org/10.1016/j.chemosphere.2014.06.046

63. M. B. Yunker, R. W. Macdonald, R. Vingarzan, R. H. Mitchell, D. Goyette, and S. Sylvestre, "PAHs in the Fraser River basin: a critical appraisal of PAH ratios as indicators of PAH source and composition," Org. Geochem. 33, 489-515 (2002).

Translated by G. Chirikova

EURASIAN SOIL SCIENCE Vol. $54 \quad$ No. $11 \quad 2021$ 